\title{
ANALISIS STRUKTUR KOMUNITAS RUMPUT (POACEAE) DI SAVANA BEKOL TAMAN NASIONAL BALURAN
}

\author{
Fajar Tri Anggara, Agus Sufajari, Fuad Ardiyansyah, N. Nurchayati \\ Program Studi Biologi, Fakultas Matematika dan Ilmu Pengetahuan Alam \\ Universitas PGRI Banyuwangi \\ Email: Fajartrianggara123@gmail.com
}

\begin{abstract}
ABSTRAK
Rumput merupakan tumbuhan yang dapat tumbuh dan hidup hampir di seluruh daerah terbuka atau terlindung baik di daerah tropis maupun sub tropis. Pada savana Bekol Keberadaan rumput saat ini tervinsasi oleh A. nilotica.Lokasi penelitian dilakukan di savana Bekol Taman Nasional Baluran. Waktu penelitian pada tanggal 12 Maret-16 Maret 2020. Metode untuk pencuplikan data struktur vegetasi Poaceae menggunakan metode purposive sampling dengan membagi wilayah menjadi tiga stasiun. hasil penelitian. Pada penelitian yang dilakukan di savana Bekol Taman Nasional Baluran didapatkan hasil 7 spesies Poaceae yaitu: Brachiaria reptans, Sclerachne punctata, Paspalum conjugatum, Polytrias amoura, Dichanthium caricosum, Themeda arguens, Rottboellia exaltata. Kemudian terdiri dari 7 genus yaitu: Brachiara, Paspalum, Polytrias, Dichanthium Willem, Themeda Forssk, Rottboellia. Pada ketiga stasiun penelitian di savana Bekol memiliki keanekaragaman yang sama yaitu sama-sama sedang Poaceae nya. Dengan rata-rata keseluruhan sebesar 1,68. Sclerachne punctata menduduki urutan teratas dengan INP diatas $80 \%$. Ini berarti Sclerachne punctata mempunyai tingkat pengguasaan tertinggi. Jenis spesies yang mempunyai nilai indeks penting (INP) tertinggi dapat digunakan untuk menentukan penamaan bentuk struktur komunitas. Dengan demikian struktur komunitas savana Bekol Taman Nasional Baluran dapat diberi nama dengan vegetasi Sclerachne punctata. Karena spesies Sclerachne punctata paling mendominasi dari seluruh stasiun penelitian.
\end{abstract}

Kata kunci: Struktur komunitas, Poaceae, Savana Bekol.

\begin{abstract}
Grass is a plant that can grow and live in almost all open or protected areas, both in tropical and sub-tropical areas. In the Bekol savanna. The existence of grass is currently invinsated by A. nilotica. The research location was conducted in the Bekol savanna of Baluran National Park. The research period was 12 March-16 March 2020. The method for collecting data on the vegetation structure of Poaceae used a purposive sampling method by dividing the area into three stations. research result. In research conducted in the Bekol savanna of Baluran National Park, 7 species of Poaceae were obtained, namely: Brachiaria reptans, Sclerachne punctata, Paspalum conjugatum, Polytrias amoura, Dichanthium caricosum, Themeda arguens, Rottboellia exaltata. Then it consists of 7 genera, namely: Brachiara, Paspalum, Polytrias, Dichanthium Willem, Themeda Forssk, Rottboellia. The three research
\end{abstract}


stations in the Bekol savanna have the same diversity, namely both being in Poaceae. With an overall average of 1.68. Sclerachne punctata topped the list with an IVI value above $80 \%$. This means that Sclerachne punctata has the highest level of mastery. Species that have the highest Importance Index (IVI) value can be used to determine the naming of community structures. Thus the structure of the Bekol Baluran National Park savanna community can be named with the Sclerachne punctata vegetation. Because the Sclerachne punctata species dominates the most of all research stations.

Keywords:Community structure, poaceae, Bekol savanna

\section{PENDAhUluAN}

Indonesia adalah salah satu negara yang memiliki kekayaan alam dan keanekaragaman hayati yang melimpah. Hal tersebut menjadikan Indonesia sebagai negara dengan kekayaan biodiversitas terbesar di dunia setelah Brasil. Kekayaan hayati salah satunya adalah keanekaragaman ekosistem. Ekosistem sangat bermanfaat untuk memenuhi kebutuhan hidup makhluk hidup di dalamnya, (Maridi, 2015).

Salah satu dari keberagaman ekosistem di Indonesia adalah ekosistem savana. Menurut Sabarno (2002), savana merupakan padang rumput dengan posisi terpencar, dan merupakan daerah peralihan antara hutan dan padang rumput. Savana pada umumnya tidak begitu terancam eksploitasi manusia untuk kepentingan ekonomi. Akan tetapi savana dapat mengalami perubahan karena penggembalaan ternak dan kebutuhan pertanian.Salah satu tempat dengan savana yang luas adalah di kawasan Bekol Taman Nasional Baluran yang terletak di kecamatan Banyuputih, kabupaten Situbondo Jawa timur. Savana di kawasan tersebut merupakan ciri khas dari Taman Nasional Baluran dan memiliki peranan penting dalam menjaga keseimbangan ekosistem lain di kawasan Taman Nasional Baluran. Karakteristik savana di Taman Nasinal Baluran memiliki hijauan yang melimpah saat musim penghujan, dan akan berkurang saat musim kemarau. Adapun ekosistem savana TN Baluran sendiri, secara topografi dibedakan menjadi savana datar (flat savanna) dengan tanah endapan (aluvial) dan savana datar sampai bergelombang (undulating savanna) dengan tanah berwarna hitam dan berbatu, (Wind dan Amir,1977). Ekosistem di savana dapat dikatakan savana merupakan ekosistem yang kurang stabil keseimbangannya. 
Keseimbangan ekosistem savana sangat dipengaruhi oleh beberapa faktor, dintaranya iklim, api, pemanfaatan oleh margasatwa dan manusia, serta adanya invasi dari tanaman Acacia nilotica. Faktor-faktor tersebut menyebabkan vegetasi rumput di savana Bekol Taman Nasional Baluran mengalami struktur fluktuatif perubahan, (Sabarno, 2002).

Berdasarkan penelitian Djufri(2012) menunjukkan bahwa spesies savana Bekol didominasi oleh 20 famili dan anatara lain yang paling mendominasi famili Poaceae 13 spesies (20,63\%), Fabaceae 11 spesies (17,46\%), Asteraceaea 8 spesies (12,70\%), Mimosaceae 5 spesies (7,94\%), Malvaceae 4 spesies (6,35\%), dan Cypraceae 2 spesies $(3,17 \%)$ ini menunjukkan bahwa komunitas Poaceae di savana Bekol melimpah. Sedangkan habitus Poaceae di savana adalah sebagai tempat mencari makanan fauna seperti banteng (Bos javanicus), kerbau liar (Bubalus bubalis), kijang (Muntiacus muntjak), dan rusa (Cervus timorensis). Sehingga menjadikannya sebagai salah satu habitat utama di Taman Nasional Baluran yang sering dijumpai rusa dan banteng makan yaitu dikawasan savana yang terbuka. Akan tetapi ada hal yang menjadi permasalahan yaitu Aacacia nilotica secara langsung dapat menurunkan produktivitas rumput.Adanya invasi tanaman eksotik A. nilotica terhadap tanaman rumput (Poaceae) savana di Taman Nasional Baluran mengakibatkan penurunan luas savana, sehingga mengakibatkan perubahan luas savana, komposisi, struktur dan produktivitas rumput pakan satwa, serta penurunan daya dukung savana terhadap penyediaan pakan bagi satwa. Hal ini berpengaruh terhadap dinamika populasi dan pola prilaku satwa khususnya banteng dan rusa(Sabarno, 2002).

Beberapa faktor diatas maka dalam hal ini perlu adanya analisis struktur vegetasi rumput di savana Bekol Taman Nasional Baluran untuk mengetahui spesies yang ada pada savana Bekol saat ini. Pada akhirnya peneliti akan mengangkat judul penelitian tentang "Analisis Struktur Vegetasi Rumput (Poaceae) di Savana Bekol Taman Nasional Baluran" yang kemudian dari data tersebut dapat dijadikan sebagai acuan penelitian selanjutnya. 


\section{METODE PENELITIAN}

\subsection{Waktu dan Tempat}

Penelitian ini dilakukan di Savana Bekol Taman Nasional Baluran yang akan dilaksanakan pada 12 Maret-16 Maret 2020 pada bulan tersebut masuk pada musim penghujan. Adapun identifikasi spesies dilakukan di perpustakaan Taman Nasional Baluran dan laboratorium Biologi Universitas PGRI Banyuwangi.

\subsection{Alat dan Bahan}

Alat yang digunakan dalam penelitian ini, sebagai berikut :

Alat tulis, kamera, meteran, plot ukuran $2 \mathrm{~m} \times 2 \mathrm{~m}$, plastik klip, kalkulator, kain flanel, termometer udara, $\mathrm{pH}$ meter, lux meter.

Bahan yang digunakan dalam penelitian ini untuk mengidentifikasi sampel yang didapat, sebagai berikut :

kertas label, buku identifikasi tentang rumput (Poaceae) (Cheklist of The Flora of Baluran National Park, 2012), tali rafia

\subsection{Metode Penelitian}

Penelitian ini menggunakan metode deskriptif kuantitatif. Metode ini bertujuan untuk mendeskripsikan suatu fenomena secara sistematis dan akurat. Sehingga pada pelaksanaanya menyajikan data angka dan tabel atau informasi yang diperoleh dari sampel yang didapatkan di Savana Bekol Taman Nasional Baluran.

\subsection{Prosedur penelitian}

Penelitian ini terdapat beberapa tahapan untuk menentukan data jumlah dan jenis rumput (Poaceae) yang ada di savana Bekol Taman Nasional Baluran. Langkahlangkah penelitian ini sebagai berikut :

\subsubsection{Observasi lapangan}

Observasi lapangan dilakukan dengan pengamatan lokasi secara langsung untuk menentukan titik obyek penelitian. Kegiatan ini untuk mengetahui keadaan awal tentang kondisi lapangan, sehingga peneliti mempunyai gambaran obyek yang akan ditelitinya.

\subsubsection{Penentuan Lokasi Penelitian}


Penelitian ini dilakukan di area Savana Bekol Taman Nasional Baluran yang memiliki 420 Ha. Lokasi tersebut dipilih karena menjadi habitat Poaceae yang paling besar di Taman Nasional Baluran. Karena didukung oleh beberapa jurnal penelitianpenelitian sebelumnya yang dilakukan di Savana Bekol Taman Nasional Baluran yang meneliti Poaceae.

Berikut ini adalah peta lokasi penelitian

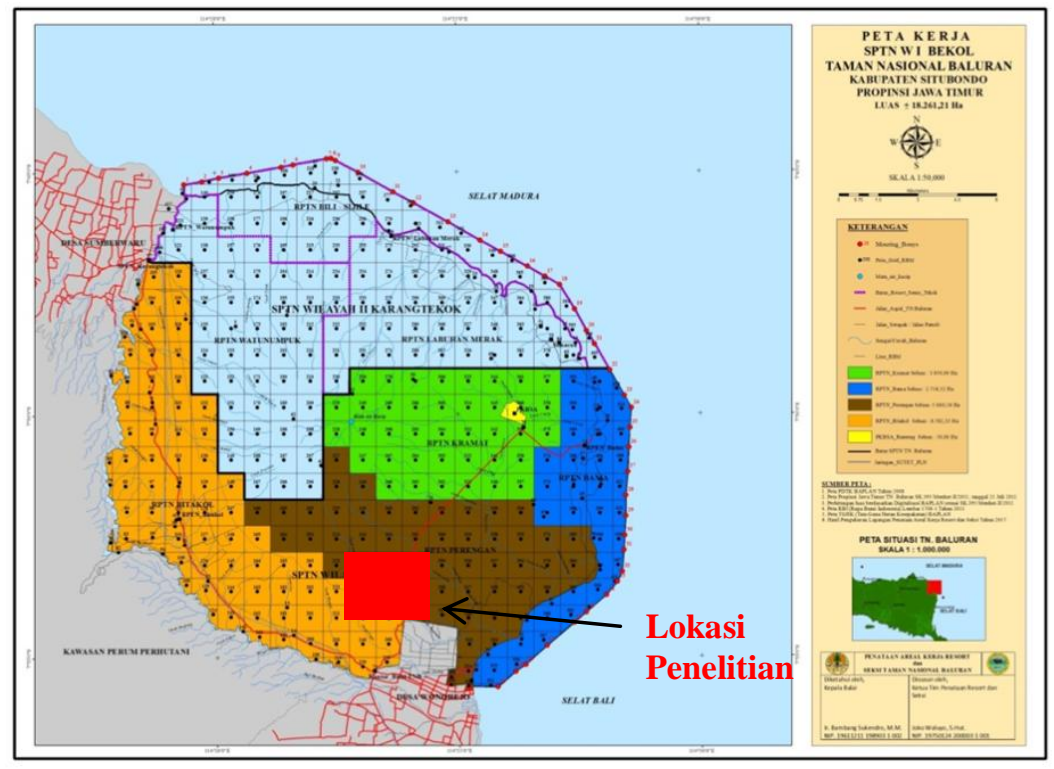

Gambar 2.1 Peta lokasi pengambilan sampel Poaceae pada savana Bekol TNB Lokasi pengambilan data penelitian ditunjukkan oleh panah.

Pencuplikan data struktur vegetasi Poaceae menggunakan metode purposive sampling. Pengambilan sampel dibagi 3 stasiun yang berbeda dengan jarak antar stasiun $50 \mathrm{~m}$ tiap garis transek sepanjang 50 meter dengan jarak antar transek sepanjang $15 \mathrm{~m}$. Per transek terdiri dari 10 petak plot yang dibagi menjadi dua yaitu sebelah kanan dan kiri yang terletak diantara jalur transek. Plot ukuran $2 \mathrm{~m} \times 2 \mathrm{~m}$ dengan 10 kali ploting dalam satu transek dengan 3 kali pengulangan dalam stasiun pengambilan sampel. Sehingga dalam satu stasiun didapatkan sebanyak 30 petak dari transek yang berbeda dan nantinya didapatkan 90 petak dari seluruh stasiun dengan luas 1,5 ha. 


\subsubsection{Pengambilan sampels}

Menurut Utomo dalam Sabarno (2002) savana Bekol hanya terdapat 75 ha yang belum terinvasi oleh $A$. nilotica. Luas tersebut hanya diambil $2 \%$ sehingga mendapatkan luas 1,5 ha yang dibagi menjadi 3 stasiun.

\subsubsection{Identifikasi sampel}

Cara identifikasi dari sampel buku identifikasi Poaceae yang berjudul Cheklist of The Flora of Baluran National Park, 2012dan jurnal-jurnal tentang Poaceae yang ada di savana Bekol sebagai salah satu sumber referensi.

\subsection{Analisis data}

\subsubsection{Indeks Keanekaragaman $\left(\mathrm{H}^{\prime}\right)$}

Analisa data dilakukan dengan cara penghitungan indeks Keanekaragaman. Keanekaragaman menunjukkan adanya kekayaan spesies dalam komunitas dan keseimbangan dalam pembagian jumlah perindividu menghitung indeks ini adalah persamaaan Shannon-Wienner (Brower, 1990).

$$
\mathrm{H}^{\prime}=-\sum\left(\frac{n i}{N}\right) \ln \left(\frac{n i}{N}\right)
$$

Keterangan :

$\mathrm{H}^{\prime}=$ indeks keanekaragaman Shannon-wienner

$\mathrm{Ni}=$ Jumlah individu jenis.

$\mathrm{N}=$ Jumlah total individu semua jenis

Kriteria penilaian indeks keanekaragaman shanon-Wiener dikelompokkan dalam 3 kriteria penilaian sebagai berikut:

$\mathrm{H}^{\prime}<1$ : Keanekaragaman rendah

$1<\mathrm{H}^{\prime}<3$ : Keanekaragaman sedang

$\mathrm{H}^{\prime}>3$ : Keanekargaman tinggi

\subsubsection{Kerapatan}

Kerapatan adalah jumlah individu per unit luas atau per unit volume. Kemudian kepentingan analisis komunitas tumbuhan, istilah yang mempunyai arti sama dengan densitas dan sering digunakan adalah kerapatan diberi notasi K ( Ardiyansa,2016 ). 
$\operatorname{Kerapatan}(\mathrm{K})=\frac{\text { Jumlah Individu }}{\text { luas seluruh petak contoh }}$

Kerapatan Relatif $(K R)=\frac{\text { Kerapatan spesies }}{\text { Kerapatan seluruh spesies }} \times 100 \%$

\subsubsection{Frekuensi}

Frekuensi dipergunakan untuk menyatakan proporsi antara jumlah sampel yang berisi suatu spesies tertentu terhadap jumlah total sampel. Frekuensi dapat dihitung dengan rumus sebagai berikut :

Frekuensi $(\mathrm{F})=\frac{\text { Jumlah petak contoh ditemukannya suatu spesies }}{\text { Jumlah seluruh petak contoh }}$

Frekuensi Relatif $(\mathrm{FR})=\frac{\text { Frekuensi } \text { suatu spesies ke }}{\text { Frekuensi seluruh spesies }} \times 100 \%$

Keterangan :

$\mathrm{F}=$ frekuensi

$\mathrm{FR}=$ frekuensi relatif

(Indriyanto,2008)

\subsubsection{Dominasi}

Dominasi adalah proporsi anatara luas tempat yang ditutupi oleh spesies tumbuhan dengan luas total habitat. Dominasi dapat dihitung dengan rumus sebagai berikut :

$\mathrm{D}=\frac{\text { Luas bidang dasar }}{\text { Luas seluruh petak ukur }}($ Ardiyansa, 2016)

$\mathrm{DR}=\frac{\text { Penutupan spesies ke-i }}{\text { Penutupan seluruh spesies }} \times 100 \%($ Ardiyansa, 2016 )

Keterangan :

$\mathrm{D}=$ dominasi

$\mathrm{DR}=$ dominasi relatif

\subsubsection{Indeks Nilai Penting}

Indeks nilai penting adalah parameter kuantitatif yang dapat dipakai untuk menyatakan tingkat dominasi (tingkat penguasaan) spesies-spesies dalam suatu komunitas tumbuhan. Indeks nilai penting dapat dituliskan dengan rumus sebagai berikut :

$\mathrm{INP}=\mathrm{KR}+\mathrm{FR}+\mathrm{DR}$ 
Keterangan :

$\mathrm{INP}=$ indeks nilai penting

$\mathrm{FR}=$ frekuensi

$\mathrm{KR}=$ kerapatan relatif

$\mathrm{DR}=$ dominasi relatif

(Indriyanto,2008)

\section{HASIL DAN PEMBAHASAN}

Berdasarkan hasil pengamatan pada seluruh stasiun yang telah dilakukan di areal Savana Bekol Taman Nasional Baluran diperoleh 7 spesies dari famili Poaceae. Jenis-jenist Poaceae yang terdapat di Savana Bekol Taman Nasional Baluran dapat dilihat pada tabel 4.1 berikut:

Tabel 3.1 Jenis-jenis Poaceae yang terdapat di Savana Bekol Taman Nasional Baluran

\begin{tabular}{lllll}
\hline No. & Famili & Genus & Spesies & Nama Daerah \\
\hline 1. & Poaceae & Brachiaria & Brachiaria reptans & Rayapan \\
\hline 2. & Poaceae & Chionachne & Sclerachne punctata & Letak \\
\hline 3. & Poaceae & Paspalum & Paspalum conjugatum & Paitan \\
\hline 4. & Poaceae & Polytrias & Polytrias amoura & Lamuran merah \\
\hline 5. & Poaceae & Dichanthium Willem & Dichanthium caricosum & Lamuran putih \\
\hline 6. & Poaceae & Themeda Forssk & Themeda arguens & Merakan \\
\hline 7. & Poaceae & Rottboellia & Rottboellia exaltata & Medhung \\
\hline
\end{tabular}

Pada pengambilan data di savana Bekol Taman Nasional Baluran didapatkan hasil 7 spesies Poaceae yaitu: Brachiaria reptans, Sclerachne punctata, Paspalum conjugatum, Polytrias amoura, Dichanthium caricosum, Themeda arguens, Rottboellia exaltata. Berdasarkan data hasil penelitian Poaceae yang dilakukan disavana Bekol Taman Nasional Baluran didapatkan jumlah Poaceae yang ditemukan, dan dapat dilihat pada tabel 4.2 berikut :

Tabel 3.2 Jumlah Poaceae yang ditemukan di savana Bekol Taman Nasional Baluran dalam setiap stasiun.

\begin{tabular}{llllll}
\hline \multirow{2}{*}{ No. } & Spesies & \multicolumn{3}{l}{ Jumlah setiap stasiun } & \multirow{2}{*}{ Jumlah } \\
\cline { 3 - 5 } & & S1 & S2 & S3 & 1346 \\
\hline 1. & Bractiara reptans & 382 & 483 & 481 & 1946 \\
\hline 2. & Sclerachne punctata & 553 & 748 & 645 & 459 \\
\hline 3. & Paspalum conjugatum & 107 & 206 & 146 & 373 \\
\hline 4. & Polytrias amoura & 103 & 145 & 125 & 22 \\
\hline \hline Analisis Struktur Komunitas Rumput (Poaceae) Di Savana Bekol Taman Nasional Baluran &
\end{tabular}


BIOSENSE Vol. 03 No. 1, Juni 2020

ISSN : $2622-6286$

\begin{tabular}{llllll}
\hline \hline 5. & Dichanthium caricosum & 74 & 100 & 95 & 269 \\
\hline 6. & Themeda arguens & 89 & 117 & 111 & 317 \\
\hline $7 . \quad$ Rottboellia exaltata & 179 & 230 & 231 & 640 \\
\hline Jumlah & 1.487 & 2.029 & 1.834 & 5.350 \\
\hline
\end{tabular}

Berdasarkan tabel 3.2 dapat diketahui jumlah rumput ( Poaceae ) yang ada di savana Bekol Taman Nasional Baluran total yang ditemukan sebanyak 5.350 individu. Rumput di savana Bekol terbanyak terdapat pada stasiun 2 dengan jumlah 2.029 individu. Sedangkan rumput yang paling sedikit ditemukan pada stasiun 1 dengan jumlah 1.487 individu. Spesies Poaceae yang banyak ditemukan disavana adalah Sclerachne punctata dengan jumlah individu 1.946 dan spesies paling sedikit adalah Dichanthium caricosum dengan jumlah individu 269. Selain itu ada juga spesies lain yang ada savana Bekol yaitu Rottboellia exaltata yang ditemukan sebesar 640 individu, Themeda arguens dengan 317 individu, Bractiara reptans dengan jumlah total 1.346 individu di savana.

Tabel 4.3 Nilai K, KR, F, FR, D, DR famili Poaceae pada stasiun 1

\begin{tabular}{|c|c|c|c|c|c|c|c|}
\hline No. & SPESIES & $\mathrm{K}$ & KR & $\mathrm{F}$ & FR & $\mathrm{D}$ & DR \\
\hline 1. & Bractiara reptans & 12.73 & 25.69 & 1.00 & 17.44 & 762.28 & 25.18 \\
\hline 2. & Sclerachne punctata & 18.43 & 37.19 & 1.00 & 17.44 & 1060.57 & 35.03 \\
\hline 3. & Eragrotis amabilis & 3.57 & 7.20 & 0.77 & 13.37 & 238.10 & 7.87 \\
\hline 4. & Polytrias amaura & 3.43 & 6.93 & 0.80 & 13.95 & 233.30 & 7.71 \\
\hline 5. & Dichantium coricosum & 2.47 & 4.98 & 0.63 & 11.05 & 172.27 & 5.69 \\
\hline 6. & Themeda arguens & 2.97 & 5.99 & 0.73 & 12.79 & 196.65 & 6.50 \\
\hline 7. & Rottboelia exaltata & 5.97 & 12.04 & 0.80 & 13.95 & 364.03 & 12.03 \\
\hline & Jumlah & 49,57 & 100,00 & 5,73 & 100,00 & 3027.0 & 100.00 \\
\hline
\end{tabular}

Berdasarkan tabel 4.3 dapat dilihat bahwa pada stasiun 1 spesies Sclerachne punctata memiliki nilai kerapatan tertinggi yaitu 18,43 dannilai kerapatan relatifnya yaitu 37,19\%. Kemudian untuk nilai kerapatan dan kerapatan relatif terendah yaitu spesies Dichantium coricosum. Dengan nilai kerapatan 2,47 dan untuk nilai kerapatan relatifnya yaitu $4,98 \%$.

Pada nilai frekuensi terdapat 2 spesies yang mempunyai nilai frekuensi yang sama yaitu Sclerachne punctata dan Brachiaria reptans yaitu 1 dan yang terendah yaitu spesies Dichantium coricosum dengan nilai 0,63 dari nilai frekuensi total seluruh spesies sebesar 5,73. Sedangkan pada nilai frekuensi relatif tertinggi terdapat 2 
spesies yaitu Sclerachne punctata dan Brachiaria reptans dengan nilai 17,44\% dan yang terendah yaitu spesies Dichantium coricosum dengan nilai 11,05\%.

Kemudian untuk nilai dominasi spesies Sclerachne punctata menjadi yang tertinggi yaitu $1.060,57 \mathrm{ind} / \mathrm{m}^{2}$ dan yang terendah spesies Dichantium coricosum dengan nilai 5,69 ind $/ \mathrm{m}^{2}$. Sedangkan dominasi relatif tertinggi yaitu Sclerachne punctata dengan nilai $35,03 \%$ dan yang terendah spesies Dichantium coricosum dengan nilai $5,69 \%$.

Tabel 4.4 Nilai K, KR, F, FR, D, DR famili Poaceae pada stasiun 2

\begin{tabular}{llrrrrrr}
\hline NO. & SPESIES & K & KR & F & FR & D & DR \\
\hline 1. & Bractiara reptans & 16.10 & 23.80 & 1.00 & 15.08 & 904.38 & 22.88 \\
\hline 2. & Sclerachne punctata & 24.93 & 36.87 & 1.00 & 15.08 & 1385.38 & 35.05 \\
\hline 3. & Eragrotis amabilis & 6.87 & 10.15 & 1.00 & 15.08 & 420.34 & 10.64 \\
\hline 4. & polytrias amaura & 4.83 & 7.15 & 1.00 & 15.08 & 307.25 & 7.77 \\
\hline 5. & Dichantium coricosum & 3.33 & 4.93 & 0.83 & 12.56 & 220.81 & 5.59 \\
\hline 6. & Themeda arguens & 3.90 & 5.77 & 0.83 & 12.56 & 251.23 & 6.36 \\
\hline 7. & Rottboelia exaltata & 7.67 & 11.34 & 0.97 & 14.57 & 462.80 & 11.71 \\
\hline Jumlah & 67,63 & 100.00 & 6,63 & 100,00 & 3952,18 & 100,00 \\
\hline
\end{tabular}

Berdasarkan tabel 4.4 dapat dilihat bahwa pada stasiun 2 spesies Sclerachne punctata memiliki nilai kerapatan tertinggi yaitu 24,93 dan nilai kerapatan relatifnya yaitu $36,87 \%$. Kemudian yang terendah yaitu spesies Dichantium coricosum dengan nilai kerapatan 3,33 dan untuk nilai kerapatan relatifnya yaitu 4,93\%.

Pada nilai frekuensi terdapat 4 spesies yang mempunyai nilai frekuensi yang sama yaitu Sclerachne punctata, Brachiaria reptans, Eragrotis amabilis, Polytrias amaura yaitu 1 dan yang terendah yaitu 2 spesies Dichantium coricosum dan Themeda arguens dengan nilai 0,83 . Nilai frekuensi relatif tertinggi terdapat 4 spesies yaitu Sclerachne punctata, Brachiaria reptans, Eragrotis amabilis, Polytrias amaura dengan nilai $15,08 \%$ dan yang terendah yaitu 2 spesies Dichantium coricosum dan Themeda arguens dengan nilai $12,56 \%$.

Kemudian untuk nilai dominasi spesies Sclerachne punctata menjadi yang tertinggi yaitu $1.385,38 \mathrm{ind} / \mathrm{m}^{2}$ dan yang terendah spesies Dichantium coricosum dengan nilai $220,81 \mathrm{ind} / \mathrm{m}^{2}$. Sedangkan untuk nilai kerapatan relatif tertinggi yaitu 
Sclerachne punctata dengan nilai $35,05 \%$ dan yang terendah spesies Dichantium coricosum dengan nilai 5,59\%.

Tabel 4.5 Nilai K, KR, F, FR, D, DR famili Poaceae pada stasiun 3

\begin{tabular}{llrrrrrr}
\hline NO. & SPESIES & K & KR & F & FR & \multicolumn{1}{c}{ D } & \multicolumn{1}{c}{ DR } \\
\hline 1. & Bractiara reptans & 16.03 & 26.23 & 1.00 & 15.08 & 918.76 & 25.19 \\
\hline 2. & Sclerachne punctata & 21.50 & 35.17 & 1.00 & 15.08 & 1218.24 & 33.41 \\
\hline 3. & Eragrotis amabilis & 4.87 & 7.96 & 0.97 & 14.57 & 312.57 & 8.57 \\
\hline 4. & polytrias amaura & 4.17 & 6.82 & 0.97 & 14.57 & 274.71 & 7.53 \\
\hline 5. & Dichantium coricosum & 3.17 & 5.18 & 0.90 & 13.57 & 218.97 & 6.00 \\
\hline 6. & Themeda arguens & 3.70 & 6.05 & 0.87 & 13.07 & 243.86 & 6.69 \\
\hline 7. & Rottboelia exaltata & 7.70 & 12.60 & 0.93 & 14.07 & 459.58 & 12.60 \\
\hline JUMLAH & 61,13 & 100,00 & 6,63 & 100.00 & 3646,68 & 100.00 \\
\hline
\end{tabular}

Berdasarkan tabel 4.5 dapat dilihat bahwa pada stasiun 3 spesies Sclerachne punctata memiliki nilai kerapatan tertinggi yaitu 21,50 dan nilai kerapatan relatifnya yaitu 35,17\%. Kemudian untuk nilai kerapatan dan kerapatan relatif terendah yaitu spesies Dichantium coricosum dengan nilai kerapatan 3,17 dan untuk nilai kerapatan relatifnya yaitu $5,18 \%$.

Pada nilai frekuensi terdapat 2 spesies yang mempunyai nilai frekuensi yang sama yaitu Sclerachne punctata dan Brachiaria reptans yaitu 1 dan yang terendah yaitu Themeda arguens dengan nilai 0,87. Kemudian untuk nilai frekuensi relatif tertinggi terdapat 2 spesies yaitu Sclerachne punctata dan Brachiaria reptans dengan nilai $15,08 \%$ dan yang terendah spesies Themeda arguens dengan nilai 13,07\%.

Kemudian untuk nilai dominasi spesies Sclerachne punctata menjadi yang tertinggi yaitu $1.218,24 \mathrm{ind} / \mathrm{m}^{2}$ dan yang terendah spesies Dichantium coricosum dengan nilai $218,97 \mathrm{ind} / \mathrm{m}^{2}$. Untuk kerapatan relatif tertinggi yaitu Sclerachne punctata dengan nilai $33,41 \%$ dan yang terendah spesies Dichantium coricosum dengan nilai $6 \%$.

Muslich (2017) mengatakan kerapatan adalah jumlah individu spesies yang dijumpai dalam petak contoh. Kerapatan suatu jenis merupakan banyaknya individu suatu jenis persatuan luas. Dengan demikian suatu jenis memiliki tingkat penguasaan yang tinggi yaitu jika memiliki nilai kerapatan yang tinggi juga.Menurut Thoyib (1984) frekuensi menunjukkan penyebaran suatu jenis dalam satu area. Spesies 
dengan frekuensi tertinggi yaitu Brachiara reptans, Sclerachne punctata, dan Paspalum conjugatum. Hal ini karena kondisi iklim di savana sangat mendukung untuk pertumbuhan segala jenis tanaman.Pertumbuhan tajuk rumput yang baik dipengaruhi oleh iklim, rumput akan tumbuh dan berkembang secara maksimal pada saat pertengahan musim hujan.Pada semua stasiun terlihat bahwa spesies Sclerachne punctata paling mendominasi. Ini berarti menunjukkan bahwa spesies Sclerachne punctata mempunyai tingkat penguasaan tertinggi diantara jenis-jenis lainnya atau merupakan jenis yang paling dominan. Menurut pendapat Djufri (2004) menjelaskan yang meyebabkan tumbuh suburnya tanaman khususnya famili Poacesae adalah jika adanya lahan terbuka yang masih belum terinvasi oleh $A$. nilotica.

Tabel 4.6 Indeks Nilai Penting (INP) pada semua stasiun.

\begin{tabular}{llrrr}
\hline NO. & SPESIES & S1 & S2 & S3 \\
\hline 1. & Bractiara reptans & 68.31 & 61.76 & 66.50 \\
\hline 2. & Sclerachne punctata & 89.67 & 86.99 & 83.65 \\
\hline 3. & Eragrotis amabilis & 28.43 & 35.86 & 31.11 \\
\hline 4. & polytrias amaura & 28.59 & 30.00 & 28.92 \\
\hline 5. & Dichantium coricosum & 21.71 & 23.08 & 24.75 \\
\hline 6. & Themeda arguens & 25.27 & 24.69 & 25.80 \\
\hline 7. & Rottboelia exaltata & 38.02 & 37.62 & 39.27 \\
\hline
\end{tabular}

Berdasarkan tabel 4.6 dapat dilihat bahwa pada stasiun 1 spesies Sclerachne punctata memiliki indeks nilai penting tertinggi yaitu $89,67 \%$, pada stasiun 2 yaitu $86,99 \%$, dan pada stasiun 3 yaitu $83,65 \%$. Untuk indeks nilai penting terendah pada seluruh stasiun yaitu spesies Dichantium coricosum. Pada stasiun 1 spesies Dichantium coricosum dengan nilai yaitu $21,71 \%$, pada stasiun 2 yaitu $23,08 \%$, dan pada stasiun 3 yaitu $24,75 \%$.

Spesies yang mempunyai INP tinggi dan sedang tersebut di atas dalam ekologi tumbuhan dikenal sebagai spesies istimewa (exclusive) artinya lebih unggul dalam nilai kuantitatif baik frekuensi dan kerapatan. Disamping itu, spesies tersebut dapat digunakan sebagai spesies indikator pada komunitas terhadap A. nilotica, baik topografi maupun kondisi habitat dan lingkungan mikronya. Sedangkan spesies lain yang memiliki INP rendah karena tidak bisa beradaptasi dengan adanya invasi $A$. nilotica. Gejala demikian umum dijumpai pada tipe vegetasi yang mengarah kepada kondisi klimaks dan stabil (Djufri, 2015). 
Tabel 4.7 Keanekaragaman ( $\left.\mathrm{H}^{\prime}\right)$ Poaceaepada semua stasiundi Savana Bekol Taman Nasional Baluran.

\begin{tabular}{llccc}
\hline \multirow{2}{*}{ No. } & Spesies & Keanekaragaman $\left(\mathrm{H}^{\prime}\right)$ & & \\
\cline { 3 - 5 } & & $\mathrm{S} 1$ & $\mathrm{~S} 2$ & $\mathrm{~S} 3$ \\
\hline 1. & Bractiara reptans & 0,35 & 0,34 & 0,35 \\
\hline 2. & Sclerachne punctata & 0,37 & 0,37 & 0,37 \\
\hline 3. & Paspalum conjugatum & 0,19 & 0,23 & 0,20 \\
\hline 4. & Heteropogon contortus & 0,18 & 0,19 & 0,18 \\
\hline 5. & Dichanthium caricosum & 0,15 & 0,15 & 0,15 \\
\hline 6. & Themeda arguens & 0,17 & 0,16 & 0,17 \\
\hline 7. & Rottboellia exaltata & 0,25 & 0,25 & 0,26 \\
\hline Jumlah & 1,66 & 1,69 & 1,69 \\
\hline Rata-rata & 1,68 & & \\
\hline
\end{tabular}

Berdasarkan tabel 4.7 dapat di ketahui nilai Keanekaragaman Poaceae pada savana Bekol Taman Nasional Baluran pada stasiun 1 indeks keanekaragaman Poaceae sebesarH ${ }^{\prime}=1,66$ menunjukkan bahwa tingkat keanekaragamannya sedang. Pada stasiun 2 indeks keanekaragaman Poaceae sebesar $\mathrm{H}^{\prime}=1,69$ menunjukkan bahwa tingkat keanekaragamannya sedang pada stasiun 2. Sedangkan pada stasiun 3 indeks keanekaragaman Poaceae sebesar $\mathrm{H}^{\prime}=1,69$ menunjukkan bahwa pada stasiun 3 juga sama dengan kedua stasiun yang lain memiliki tingkat keanekaragaman Poaceae yang sedang. Berarti dapat disimpulkan bahwa pada ketiga stasiun di atas memiliki keanekaragaman yang sama yaitu sama-sama sedangPoaceaenya. Dengan rata-rata keseluruhan sebesar $\mathrm{H}^{\prime}=1$,68.Indriyanto (2006) menyatakan bahwa keanekaragaman spesies dagat digunakan untuk menyatakan struktur komunitas. Keanekaragaman juga dapat digunakan untuk mengukur stabilitas komunitas, yaitu kemampuan suatu komunitas untuk menjaga dirinya tetap stabil meskipun ada gangguan terhadap komponen-komponennya.

Dari hasil pengambilan data disavana Bekol Taman Nasional Baluran terdapat faktor lingkungan yang ditunjukkan pada tabel 4.8 berikut:

Tabel 4.8 Faktor lingkungan Poaceae di savana Bekol Taman Nasional Baluran.

\begin{tabular}{lllllll}
\hline No. & Parameter & Satuan & Alat & S1 & S2 & S3 \\
\hline 1. & Suhu & $\mathrm{C}$ & $\begin{array}{l}\text { Termometer } \\
\text { Batang }\end{array}$ & 32,8 & 30,2 & 31,4 \\
\hline 2. & Intensitas Cahaya & Lux & Lux meter & 4.078 & 3.986 & 4.027 \\
\hline 3. & Derajat keasaman tanah & $\mathrm{pH}$ & $\mathrm{pH}$ tanah & 5,5 & 5,8 & 5,6 \\
\hline
\end{tabular}

Berdasarkan Tabel 4.8 faktor lingkungan Poaceae di savana Bekol Taman Nasional Baluran diketahui untuk parameter disemua stasiun berkisar $30,2-32,8^{\circ} \mathrm{C}$. Parameter suhu menunjukkan bahwa pada stasiun 1 sebesar $32,8{ }^{\circ} \mathrm{C}$, pada stasiun 2 sebesar $30,2^{\circ} \mathrm{C}$, dan pada stasiun 3 sebesar $31,4{ }^{\circ} \mathrm{C}$. Sedangkan pada parameter 
intensitas cahaya pada stasiun 1 sebesar 4.078 lux, pada stasiun 2 sebesar 3.986 lux, dan pada stasiun 3 sebesar 4.027 lux. Kemudian untuk selanjutnya yaitu pada parameter $\mathrm{pH}$ pada stasiun 1 sebesar 5,5, stasiun 2 sebesar 5,8, dan pada stasiun 3 sebesar 5,6.

\section{KESIMPULAN DAN SARAN}

Berdasarakan hasil penelitian yang dilakukan pada savana Bekol Taman Nasional Baluran, maka dapat diambil kesimpulan sebagai berikut :

1. SpesiesPoaceae yang terdapat di savana Bekol Taman Nasional Baluran ada 7 spesies Poaceae yaitu: Brachiaria reptans, Sclerachne punctata, Paspalum conjugatum, Polytrias amoura, Dichanthium caricosum, Themeda arguens, Rottboellia exaltata. Kemudian terdiri dari 7 genus yaitu: Brachiara, Paspalum, Polytrias, Dichanthium Willem, Themeda Forssk, Rottboellia.

2. Struktur komunitasPoaceae yang terdapat di savana Bekol Taman Nasional Baluran yang mempunyai nilai penting tertinggi adalah Sclerachne punctata dengan nilai diatas $80 \%$ pada setiap stasiunnya. Mempunyai tingkat penguasaan tertinggi diantara spesies yang lainnya atau merupakan spesies Poaceae yang dominan.

\section{Saran}

1. Penelitian selanjutnya diharapkan melakukan penelitian pada area lebih luas lagi agar mendapatkan hasil yang maksimal dan memperoleh spesies Poacea yang lebih beranekaragam.

2. Perlu dilakukan penelitian lanjutan tentang analisis struktur vegetasi pada famili tumbuhan bawah lain yang ada pada savana Bekol Taman Nasional Baluran.

\section{REFERENSI}

Djufri, 2004. Pengaruh Kerapatan Akasia (Acacia Nelotica) (L.) Willd. Ex. Del. Terhadap Komposisi Dan Keanekaragaman Tumbuhan Bawah Di Taman Nasional Baluran Jawa Timur.

Djufri,2012. Analisis Vegetasi Pada Savana Tanpa Tegakan Akasia (Acacia Nilotica)

Di Taman Nasional Baluran Jawa Timur.Dosen Program Studi Pendidikan Biologi FKIP Universitas Syiah Kuala Banda Aceh. 
Djufri. 2015. Prosding Seminar Nasional Biotik 2015. Analisis Vegetasi Pada Tegakan Yang Terinvasi Akasia (A. Nilotica) Di Taman Nasional Baluran Jawa Timur. Jurusan Pendidikan Biologi FKIP Universitas Syiah Kuala Darussalam Banda Aceh.

Hardjosuwarno, S, 1990. Dasar-Dasar Ekologi Tumbuhan. Yogyakarta : Fakultas Biologi Universitas Gadjah Mada.

Hidayat Muslich, 2017. Analisis Vegetasi Dan Keanekaragaman Tumbuhan Di Kawasan Manifestasi Geotermal IE SUUM Kecamatan Mesjid Raya Kabupaten Aceh Besar. Program Studi Pendidikan Biologi Fakultas Tarbiyah Dan Keguruan UIN Ar-Rainiry. Banda Aceh.

Maridi,2015. Analisis Struktur Vegetasi Di Kecamatan Ampel Kabupaten Boyolai. Prodi Pendidikan Biologi FKIP Universitas Sebelas Maret Surakarta.

Marsono Dan Thoyib, 1984. Ekosistem Hutan Tropika Humida. Yogyakarta Kerjasama Fakultas Kehutanan UGM Dengan Proyek Pendidikan Latihan Dan Pengendalian Tenaga Kerja Pengusahaan Hutan Departemen Kehutanan Syogyakarta.

Sabarno Yusuf .M, 2002. Savana Taman Nasional Baluran. Balai Taman Nasional Baluran Situbondo Jawa Timur.

Saputra, Dwi, Ardiyansa. 2016. Komposisi,Struktur, Dan Keanekaragaman Jenis Vegetasi Di Jalur Wisata Air Terjun Wiyono Atas Taman Hutan Raya Wan Abdul Rachman Provinsi Lampung. Fakultas Pertanian Universitas Lampung. Bandar Lampung.

Wind, J. And H. Amir.1977. Proposed Baluran National Park Management Plan 1978/1979-1982/1983.Prepared For The Directorat Of Nature Conservation, Directorat General Of Forestry, Republic Of Indonesia.Nature Conservation And Wildlife Management Project Of The Food And Agriculture Organisation Of The Sunited Nations. 